\section{First record of Yellow-bellied Sea Snake Pelamis platurus (Linnaeus, 1766) (Reptilia: Hydrophiidae) from a riverine tract in northern Kerala, India}

\author{
Muhamed Jafer Palot ${ }^{1}$ \& C. Radhakrishnan ${ }^{2}$ \\ 1,2 Western Ghat Regional Centre, Zoological Survey of India, \\ Eranhipalam. P.O. Kozhikode, Kerala 673006, India \\ Email: ${ }^{1}$ jaferpalot@gmail.com
}

The family Hydrophiidae is a highly specialized group of exclusively marine snakes represented by 58 species in the world (Guinea 2003). Distribution of sea snakes is generally restricted to tropical and subtropical regions of the Indian and Pacific oceans. Studies on sea snakes tend to be poor because of logistic difficulties inherent in sampling them. Most of the studies on sea snakes rely on the incidental capture in commercial fishing operations and specimens washed ashore.

On 23 and 30 May 2009, two specimens of the Yellowbellied Sea Snake Pelamis platurus were collected from the tidal waters of Kallayi River in Kozhikode District (Image 1) and from the inland riverine tract of Vadickalkadavu area in Kuppam River in Kannur District respectively, in northern Kerala. Kallayi is situated about $1 \mathrm{~km}$ east from the sea mouth, whereas, the Vadickalkadavu area in Kuppam River is situated about $5 \mathrm{~km}$ from the sea mouth of Azheekkal. The two specimens (one each from each locality) were entangled in fishing nets and were found

Date of publication (online): 26 August 2010

Date of publication (print): 26 August 2010

ISSN 0974-7907 (online) | 0974-7893 (print)

Editor: Ashok Captain

Manuscript details:

Ms \# 02284

Received 18 August 2009

Final revised received 03 August 2010

Finally accepted 04 August 2010

Citation: Palot, M.J. \& C. Radhakrishnan (2010). First record of Yellow-bellied Sea Snake Pelamis platurus (Linnaeus, 1766) (Reptilia: Hydrophiidae) from a riverine tract in northern Kerala, India. Journal of Threatened Taxa 2(9): 1175-1176.

Copyright: (c) Muhamed Jafer Palot \& C. Radhakrishnan 2010. Creative Commons Attribution 3.0 Unported License. JoTT allows unrestricted use of this article in any medium for non-profit purposes, reproduction and distribution by providing adequate credit to the authors and the source of publication.

Acknowledgements: The authors are grateful to the Director, Zoological Survey of India, Kolkata for facilities and encouragement. Thanks are also due to $\mathrm{Dr}$. K. Kishore Kumar, Nature Education Officer, Malabar Natural History Society, Kozhikode for the help rendered during the collection of the specimen from Kallayi, Kozhikode District.

\section{OPEN ACCESS | FREE DOWNLOAD @C (i) ৫)}

alive. Identity of the specimens was confirmed visually, based on a description in Whitaker \& Captain (2004): head and dorsal surface shiny black; underside canary yellow; tail creamish-white, with large black spots; marks on upper edge of tail, alternate with those on lower edge.

The specimen from Kallayi River was kept in an aquarium tank for further observations. In captivity, it did not take any food even though small live freshwater fishes and dead marine fishes were offered. It survived for 25 days in the aquarium tank without showing any discomfort in freshwater. The snake was agile and dived with ease. At times it was observed making complex loops and coils and running the knots from one end of its body to the other. It also exhibited its ability to swim backwards.

The fishermen in the coastal villages of northern Kerala are very familiar with this snake and it is locally known as Manjakurishipambu, (Manjakurishi = yellowish; pambu = snake) owing to its striking yellow and black colour. The maximum length recorded for this sea snake is $98 \mathrm{~cm}$ (Murthy 2007), while the one collected from Kallayi River was only $40 \mathrm{~cm}$ and the one from Kuppam River much smaller measuring only $29 \mathrm{~cm}$.

Twenty species of sea snakes have been recorded from the coastal waters of India (Smith 1943; Whitaker \& Captain 2004; Murthy 2007). There is little information on the distribution and biology of sea snakes occurring in the coastal waters of India. Murthy (1977) and Kalairasan and Kanakasabai (1994) reported 10 species belonging to seven genera from the Chennai coast. Tripathy (2006) reported occurrence of two species of sea snakes from Rishikulya, Orissa coast. Goa coast is known for six species (Lobo 2003). Except for a trawl by-catch study of four species (Enhydrina schistosa (Daudin), Hydrophis cyanocinctus Daudin, Hydrophis ornatus (Gray), and Lapemis curtus (Shaw)) by Bijukumar et al. (2007), no detailed study is available on the marine snake species off the coast of Kerala.

The Yellow-bellied Sea Snake is the most widely distributed sea snake. It is seen throughout the tropical regions of the Indian and Pacific Oceans, till the west coast of Central America and is also recorded from the east African coast. Normally these snakes live in waters with temperature varying between 11.7 and $36{ }^{\circ} \mathrm{C}$.

In India the Yellow-bellied Sea Snake is reported from Chennai coast (Ahamed 1975; Murthy 1997; Kalairasan \& Kanakasabai 1996), Orissa coast (Tripathy 2006) and the coastal waters of Goa (Lobo 2003). The species was not listed by Bijukumar et al. (2007) in the survey of Kerala coast. Therefore, the present report forms the first authentic record of the species from the coastal waters of Kerala. The specimens are deposited at Zoological Survey of India, Western Ghats Regional Centre, 


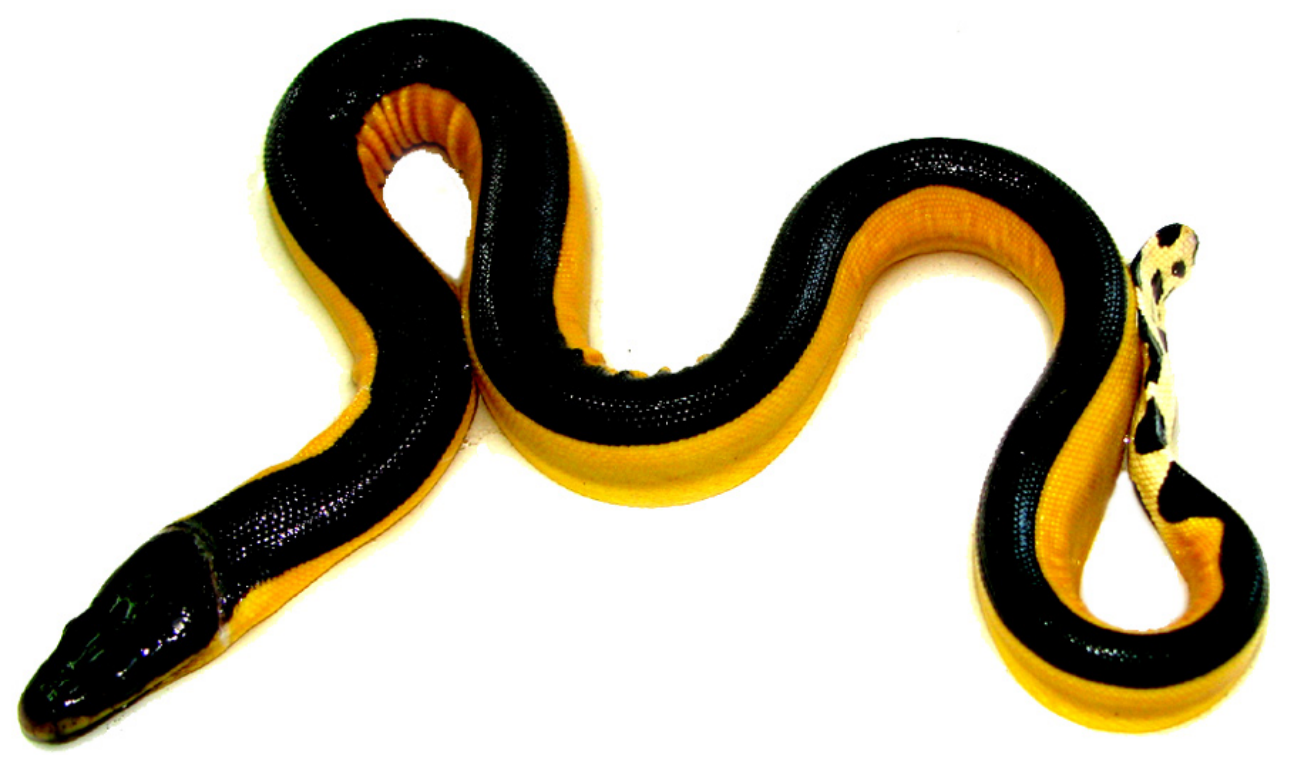

Image 1. Yellow-bellied Sea Snake Pelamis platurus (Linnaeus)

Kozhikode, Kerala (Reg. Nos. 2127 and 2128).

\section{REFERENCES}

Ahamed, S. (1975). Sea snakes of the Indian Ocean in the collection of the Zoological Survey of India together with remarks on the geographical distribution of all Indian ocean species. Journal of the Marine Biological Association of India 17(1): 73-81.

Bijukumar, A., M. S. Kumar, G.R. Deepthi \& S. Mithun (2007). Sea snakes associated with trawl by-catch of Kerala coast, India. Cobra I(1): 1-4.

Guinea, M.L. (2003). Ecology, Systematics and Biogeograhy of Sea Snakes. Faculty of Education, Health and Sciences, Northern Territory University, Darwin, Australia.

Kalairasan,V. \& R. Kanakasasbai (1994). Seasonal availability of Sea snakes (Family: Hydrophiidae) in the Madras waters.
Cobra 16: 18-19.

Murthy, T.S.N. (1977). On Sea snakes occurring in Madras waters. Journal of the Marine Biological Association of India 19(3): 68-72.

Murthy, T.S.N. (2007). Pictorial Handbook on Marine Reptiles of India. Zoological Survey of India, Kolkata, 75pp.

Smith, M.A. (1943). The Fauna of British India. Vol.III - Snakes. Taylor and Francis, London, 583pp

Tripathy, B. (2006). Observations on Hook-nosed Sea snake, Enhydrina schistosa (Daudin) and Black and Yellow Sea Snake, Pelamis platurus (Linnaeus) at Rishikulya, Orissa, India. Cobra 63: 4-6.

Lobo, A.S. (2003). Sailing with Serpents. Sanctuary Asia Magazine XXIII(6): 34-39

Whitaker, R. \& A. Captain. (2004). Snakes of India-The Field Guide. Draco Books, Chennai, India, 481pp. 